\title{
溶射サーメット (WC-Co) 皮膜の組織と特性
}

\section{Structure and Properties of Thermal Sprayed Cermet (WC-Co) Coatings}

\author{
黒田聖治*・渡邊 誠* \\ Seiji KURODA and Makoto WATANABE
}

Key Words: Wear Resistance, Carbides, HVOF, Warm Spray, Decarburization, Rapid Solidification, Hardness, Toughness, Cold Spray

\section{1. 緒 言}

溶射皮膜の主要な適用分野に耐摩耗コーティングがあ り、産業界の広い分野で実績がある。近年は、硬質クロム メッキの代替技術としても航空機のランディングギアを始 めとして、種々の機器で検討が進められている。皮膜材料 としては、アルミナ等のセラミックスや WC-Co 等のセラ ミックスと金属を複合化したサーメットが用いられる場合 多いが、特に後者は高速フレーム (High Velocity Oxy-fuel: HVOF) 溶射法が開発されてから皮膜の特性が向上し、製鉄・ 製鋼ライン、製紙・印刷機器、化学装置、金型等の広い分 野に用途が拡大している。

材料面では、WC-Coに代表される超硬合金は、焼結体 として硬さと破壊勒性の両特性に優れることから、各種切 削工具や耐摩耗性が要求される様々な用途に用いられてお $\eta^{1)}$ 、溶射サーメット皮膜の基本材料とも考えられる。そ の原料となるタングステン鉱石の埋蔵量は極少数の産出国 に偏在しており、2003 年では世界の生産量のおよそ $83 \%$

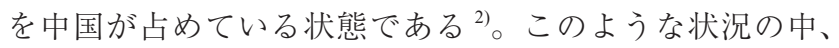
近年、世界的な需要の増加と産出国の国家的資源戦略によ り、WCの原料価格は高騰しており、資源確保が困難な状 況も起きつつあり、WC 自体の使用量の減少およびその再 利用を可能とする技術が求められている。この省資源化の 一つのアプローチとして、WC-Co コーティング材を用いる ことにより、焼結バルク体の利用分野を一部代替すること が考えられる。安価かつ資源豊富な鉄系基材を用いて、表 面のみをコーティングすることにより、WC 使用量の大幅 な低減が期待出来る。

本稿では、サーメット材料、溶射プロセス、HVOF 溶射 によるサーメット皮膜及び近年 NIMS が開発したウォーム スプレーによるサーメット皮膜の組織と特性について、主 にWC-Co を例として解説する。

\section{2. 高速フレーム溶射法とウォームスプレー法}

サーメット材料のコーティング技術としては、高速フ レーム (HVOF) 溶射が現在、最も広く利用されている ${ }^{3-5}$ 。 HVOF 溶射法の原理を Fig.1 (a) に示す。燃料としては可然 ガス（プロピレン、アセチレン、水素等）や灯油を用い、 酸素と燃焼室中で混合・燃焼させてノズルから噴出させる ことによって超音速の高温ガス流を発生させ、その中に原 料粉末を注入し、加速・加熱させて基材上に衝突させるこ とにより成膜する。通常、その粒子速度は $500 \mathrm{~m} / \mathrm{s}$ を超え、

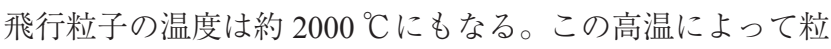
子が溶融または半溶融状態で基材に衝突し、積層し皮膜が 形成される。基材に投射される粒子速度が高いために非常 に緻密かつ密着性の良い皮膜を作成することができる。

しかし、代表的なサーメット材料である WC-Co を例に とると、後述するように HVOF 溶射により作成された皮膜 であっても、その破壊特性は焼結バルク体と比較して大き く劣り、利用分野の拡大において大きな壁となっている ${ }^{6,7)}$ 。

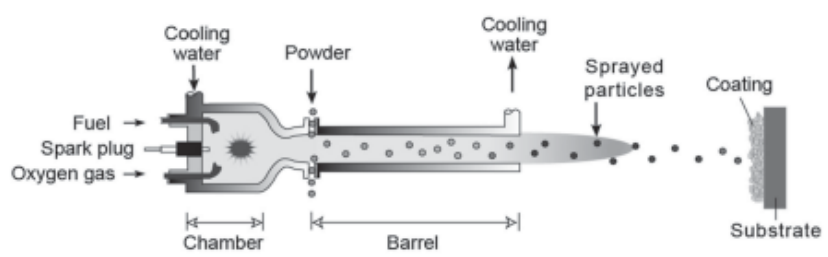

(a) HVOF

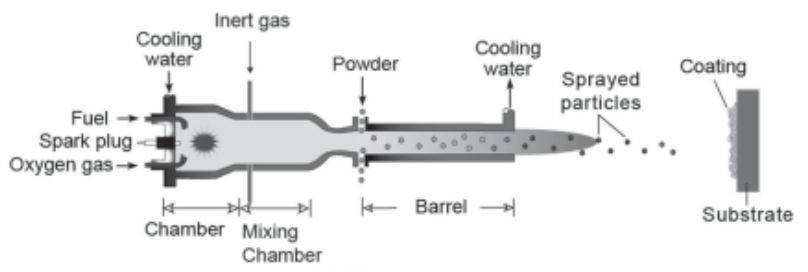

(b) Warm Spray

Fig.1 Schematics of High Velocity Oxy-Fuel (HVOF) spray (a) and Warm Spray (WS) (b) apparatus.

* (独)物質・材料研究機構ハイブリッド材料センター（† 305-0047 茨城県つくば市千現 1-2-1）

National Institute for Materials Science, Hybrid Materials Center (1-2-1, Sengen, Tsukuba, Ibaragi, 305-0047, Japan) 
高 温 学 会 誌 第 36 巻 第 6 号 (2010 年 11 月)

Table 1 Typical spray conditions of HVOF and WS for WC-Co coatings.

\begin{tabular}{lcc}
\hline & HVOF & WS \\
\hline Barrel length $(\mathrm{mm})$ & 152 & 203 \\
Spraying distance $(\mathrm{mm})$ & 380 & 200 \\
Fuel (I/min) & 0.38 & 0.38 \\
Oxygen (I/min) & 944 & 778 \\
Nitrogen (I/min) & - & 500 \\
Powder feed rate (g/min) & 80 & 80 \\
\hline Powder feed gas & Nitrogen & Nitrogen \\
\hline
\end{tabular}

溶射皮膜の脆さの要因として、溶射プロセス時における (i) $\mathrm{WC}$ の脱炭反応による脆性な $\mathrm{W}_{2} \mathrm{C}$ 相の生成、(ii) $\mathrm{WC}$ の $\mathrm{Co}$ バインダーへの溶解による脆性な $\eta$ 相 $\left(\mathrm{W}_{3} \mathrm{Co}_{3} \mathrm{C}, \mathrm{W}_{2} \mathrm{Co}_{4} \mathrm{C}\right.$ 等) やアモルファス相の生成が主な要因であると考えられ ている ${ }^{6,8,9)}$ 。不活性雲囲気中において焼結法等により作成 される WC-Co バルク体が、純粋に WC と Co の二相からな るのに対し、HVOF 溶射法により作製される皮膜は化学組 成、治金的組織の観点からかなり異なるものになっている。 このため、これら溶射プロセス時の劣化反応を抑え、かつ 緻密な皮膜を作成することが出来れば、現在の WC-Co コー ティング材の特性を飛躍的に改善させることが十分に期待 できる。

この考えに沿ったプロセスが二段式 HVOF 溶射（通称 ウォームスプレー：WS）であり、その原理図を Fig.1 (b) に示す。通常の HVOF 溶射装置の燃焼室と粉末供給口の 中間に混合室を設け、そこに室温の不活性ガス（通常は窒 素）を吹きこんでガス温度を低下させてから粉末を吹きこ み、加熱・加速して基材に吹き付ける。粉末供給地点での ガス温度は窒素流量によって大幅に変化させることが可能 で、およそ 2000 〜 $500{ }^{\circ} \mathrm{C}$ の間が制御範囲である。近年、コー ルドスプレーにおいてもガス温度を上昇させる方向で装置 開発が進められており、最新の機種では $1000{ }^{\circ} \mathrm{C}$ 到達し つつある。従って、Warm Spray は HVOF とコールドスプ レーの中間の温度領域の溶射法と言える。プロセスの考え 方の基本は、粉末粒子を溶融させずに材料の劣化を制御し、 融点以下の軟化状態で高速度に基材に堆積させ、付着効率 や皮膜の緻密化を達成しようとするものである。Table 1 に本報告で引用される研究で主に用いた HVOF 及び WS 装 置の代表的な動作条件を示す。燃料は灯油で、酸素と混 合・霧化されて、燃焼室に吹きこまれて連続的に燃焼する。 WC-Co に関しては、窒素流量は毎分 $0.5 \mathrm{~m}^{3}$ とWS としては 低めの值であり、材料によっては $1 \mathrm{~m}^{3} / \mathrm{min}$ 以上の流量も用 いられる。これまでにチタンやWC-Co、金属ガラス、酸化 チタン、高分子材料（PEEK）等についての報告がなされて いる ${ }^{10)}$ 。
Table 2 Major carbide-based feedstock materials for HVOF spraying in the market.

\begin{tabular}{|c|c|c|c|c|}
\hline \multirow{5}{*}{ WC 系 } & WC/Co & $\begin{array}{l}\text { WC/12Co, } \\
\text { WC/17Co }\end{array}$ & Hv1300 & $\begin{array}{l}\text { 超硬品の代替・粉 } \\
\text { 砕機底板・スクリー } \\
\text { ン }\end{array}$ \\
\hline & $\mathrm{WC} / \mathrm{Ni}$ & WC/30Ni & Hv870 & $\begin{array}{l}\text { 耐食・耐摩耗に優 } \\
\text { れる }\end{array}$ \\
\hline & $\mathrm{WC} / \mathrm{CrC} / \mathrm{Ni}$ & $\mathrm{WC} / 2 \mathrm{OCr}_{3} \mathrm{C}_{2} / 7 \mathrm{Ni}$ & Hv1200 & $\begin{array}{l}\text { 耐高温酸化に優れ } \\
\text { る・製紙ロール }\end{array}$ \\
\hline & $\mathrm{WC} / \mathrm{Co} / \mathrm{Cr}$ & WC/10Co/4Cr & Hv1150 & $\begin{array}{l}\text { 耐酸化・耐食に優 } \\
\text { れる }\end{array}$ \\
\hline & $\mathrm{WC} / \mathrm{NiCr}$ & WC/27NiCr & Hv1000 & $\begin{array}{l}\text { WC 自溶合金・オ } \\
\text { キサイドフリーの } \\
\text { 皮膜・製紙ロール }\end{array}$ \\
\hline CrC 系 & $\mathrm{CrC} / \mathrm{NiCr}$ & $\begin{array}{l}\mathrm{Cr}_{3} \mathrm{C}_{2} / 20 \mathrm{NiCr}, \\
\mathrm{Cr}_{3} \mathrm{C}_{2} / 25 \mathrm{NiCr}\end{array}$ & Hv1000 & $\begin{array}{l}800^{\circ} \mathrm{C} \text { 耐フレッティ } \\
\text { ング・マンドレル } \\
\text { ボイラーチユーブ }\end{array}$ \\
\hline
\end{tabular}

\section{3. サーメット溶射材料}

サーメット溶射材はセラミックスと金属を何らかの方法 で組み合わせたもので、セラミックスとしては酸化物、炭 化物、ホウ化物、ケイ化物、窒化物等が用いられる。これ まで国内外で研究されてきたサーメット溶射材の種類は数 多くあるが、市販されているサーメット溶射材料のほとん どは炭化物系であり、その中でも $\mathrm{WC}$ 系と $\mathrm{Cr}_{3} \mathrm{C}_{2}$ 系が最も 多い。一般的に WC 系は低温域 (500 ${ }^{\circ} \mathrm{C}$ 以下)、 $\mathrm{Cr}_{3} \mathrm{C}_{2}$ 系は 高温域 $\left(900{ }^{\circ} \mathrm{C}\right.$ 以下）での使用に有効とされ、腐食環境で 使用される場合はサーメット中の金属成分に耐食性を向上 させる $\mathrm{Cr}$ や $\mathrm{Ni}$ 等を添加することが多い。Table 2 に市販 されているサーメット溶射材の特性とその用途を示す。

サーメット皮膜を得る為に単にセラミック粉と金属粉を ブレンドして溶射しただけでは、優れた溶射皮膜を得るこ とは難しい。この場合、セラミック粒子単体は、基材に付 着せずにリバウンドすることもあり、結果として皮膜中の セラミック粒子の割合が少なくなる可能性も大きい。一般 的にサーメット粉末は焼結 - 粉砕法、あるいは造粒 - 焼結 法と呼ばれる製法によって単一粒子の中にセラミックと金 属を複合化して作製されており、多くのメーカーは造粒一 焼結法によって製造している。この造粒一焼結法とは微粉 末を混合、造粒した後に焼結し、解砕・分級したものである。 サーメット溶射材料については、文献が詳しい ${ }^{11)}$

\section{HVOF 溶射皮膜の組織と特性}

\subsection{HVOF 溶射した WC-Co 皮膜の組織}

近年、Pornthep らは代表的なサーメット溶射材である WC-Co に着目し、HVOF 溶射皮膜の組織と特性に関して系 統的な研究を行った ${ }^{0}$ 。その要約を以下に紹介する。Table 3 が用いられた WC-Co 造粒焼結粉の組成と密度である。材 料側のパラメータとして、WC の粒子径と Co の量に注目し、 前者の平均值としては $0.2 、 2 、 6 \mu \mathrm{m} の 3$ 種類、後者として 
Table 3 Feedstock powders of WC-Co used in the study.

\begin{tabular}{|c|c|c|}
\hline \multicolumn{2}{|c|}{ Powder } & \multirow{2}{*}{$\begin{array}{c}\text { Density } \\
\left(\mathrm{g} / \mathrm{cm}^{3}\right)\end{array}$} \\
\cline { 1 - 2 } WC size & \%Co & 5.63 \\
0.2 & 8 & 4.97 \\
0.2 & 12 & 4.48 \\
0.2 & 17 & 4.13 \\
0.2 & 25 & \\
& & 4.43 \\
2 & 8 & 4.5 \\
2 & 12 & 3.94 \\
2 & 17 & 3.65 \\
2 & 25 & \\
& & 4.51 \\
6 & 8 & 4.09 \\
6 & 12 & 3.71 \\
6 & 17 & 3.61 \\
6 & 25 & \\
\hline
\end{tabular}

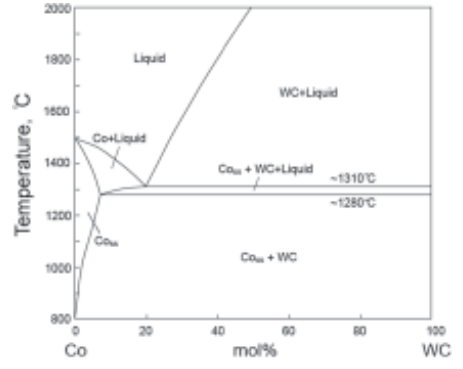

(a)

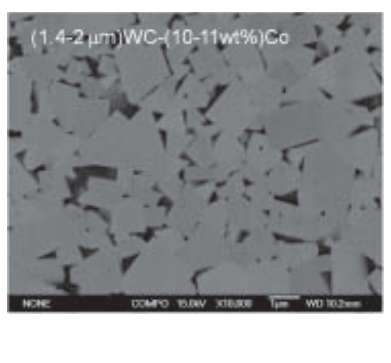

(b)
Fig.2 Pseudo binary phase diagram of WC-Co system (a) and a typical microstructure (back scattered electron image) of sintered WC-Co bulk (b).

8、12、17、 $25 \mathrm{wt} \%$ の 4 種類、計 12 種類の原料粉末が用意 された。HVOF 溶射条件は、Table 1 に示した標準条件で 一定とされた。

Fig.2 は WC-Co の擬二元系状態図 (a) と、焼結体の断面 組織像（後方散乱電子：BSE 像）(b)である。WC-Co は超 硬合金として切削工具等に広く用いられている材料であ り、液相焼結法が製造に用いられる。状態図から分かるよ うに、この系は、WC と Co の間には他の化合物は存在せず、 高温で出現する液相中には WC が 20 \% 以上溶解する。こ のため、溶融したCoは WCに対して濡れ性に優れており、 液相は WC 粒子の隙間を容易に充填する。緻密化した後に 温度を下げていくと、液相中に過剩に溶解した WC は再び 析出して、最終的には WC-Co の二相組織に戻る。Fig.2 (b) の組織は、WCの結晶を均質な Co バインダー相が結びつ けている状態をよく示している。この組織によって超硬合 金は優れた硬度と勒性を併せ持つと考えられる。

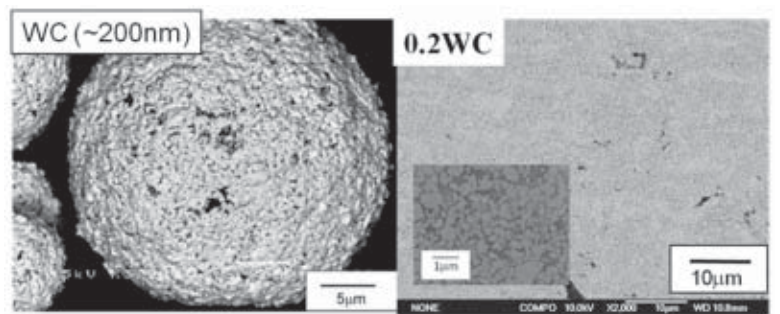

(a)

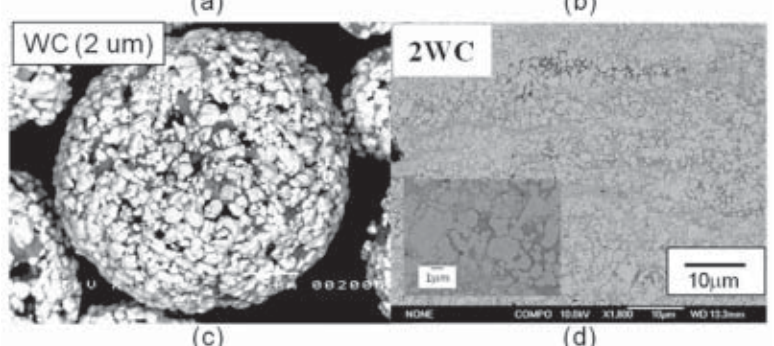

(c)

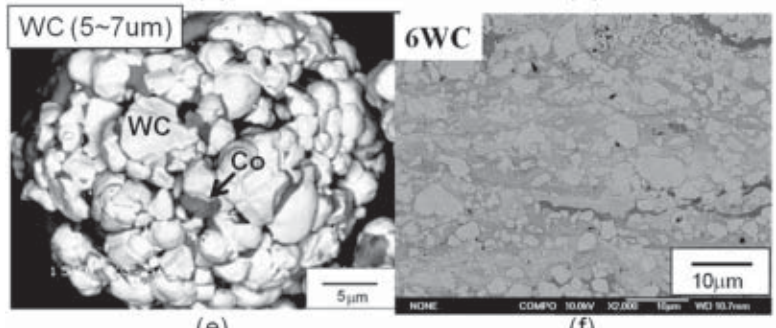

(e)

(f)

Fig.3 BSE images of feed stock powders with different WC size Wit $12 \%$ Co content (a, c, e) and corresponding HVOF coating cross sections $(b, d, e)$

Fig.3 は $12 \mathrm{wt} \% \mathrm{Co}$ の組成で WC 粒径が異なる粉末と、対 応する HVOF 溶射皮膜断面組織の BSE 像である。原料は $\mathrm{WC}$ 粒子と Co 粒子がある程度の空隙を残しつつも一体化 した状態であることが分かり、さらに Table 3 の粉体の見 掛け密度からも WC 粒径の粗い粉末ほど、密度が低い傾向 が認められる。得られた皮膜中の WC 粒子は、角が丸く、 またかなり小さくなっているものも認められ、溶射時の高 温で溶融Co 中に溶出したことが分かる。また、Coリッチ なバインダ相のコントラストが不均一になっており、WC が溶け込んだ部分は明るくなっている。これらのことから、 HVOF 溶射では、Coバインダーが溶融し WC が溶出、基 材上の衝突・堆積後の急冷によって合金化したバインダー 組成がそのまま皮膜に出現していることが分かる。また、 WC の溶出量は皮膜中でかなりばらつきがある。Fig.4 は原 料粉末の Co 量が異なる場合の HVOF 皮膜の断面組織であ るが、Co 量が多いほど Co 相の合金化の程度が大きいこと が見て取れる。さらに、高温では脱炭反応、酸化反応も進 んでおり、Fig.5に示す皮膜の X 線回折（XRD）スペクト ルには WC-Co 状態図上には無い、 $\mathrm{W}_{2} \mathrm{C}$ や W も出現してい る。また、Coのピークが非常に広がっており、急冷凝固 によってナノ結晶、アモルファス化しているとの報告があ る $^{12,13)}$ 。 

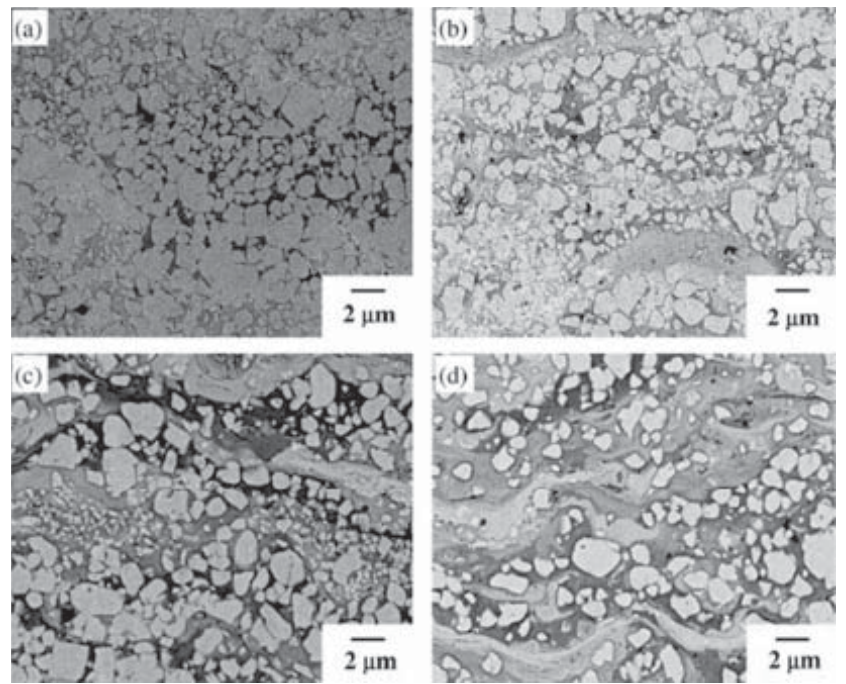

Fig.4 BSE images of HVOF WC-Co coatings of $2 \mathrm{~mm}$ WC with different Co contents: (a) $8 \%$, (b) $12 \%$, (c) $17 \%$, and (d) $25 \%{ }^{6}$.

$\bullet: \mathrm{WC} \quad \square: \mathrm{W}_{2} \mathrm{C} \quad \Delta: \mathrm{W} \quad \bullet: \mathrm{Co}$
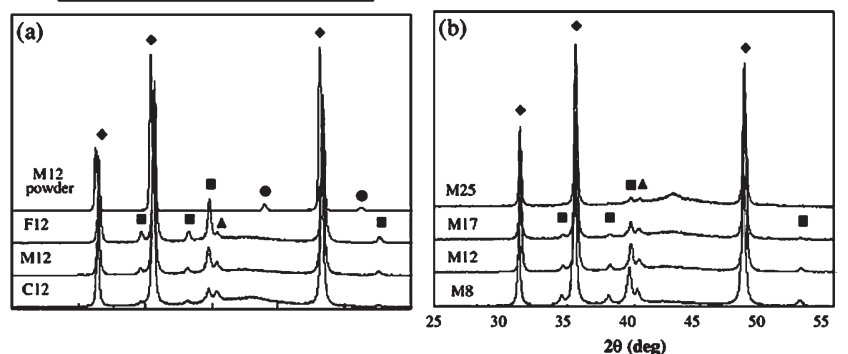

Fig.5 XRD spectra of coatings from 12 Co powders with different WC sizes (a) and medium size $(2 \mathrm{~mm}) \mathrm{WC}$ coatings with different Co contents (b) ${ }^{6}$.

\section{2 溶射した WC-Co 皮膜の機械特性}

Fig.7は、HVOF 溶射皮膜の硬度を断面組織から算出さ れた実際の炭化物量を横軸にプロットしたもので、点線は 文献による焼結体の值である。溶射皮膜中の炭化物量は、 バインダー相中への溶出、さらには基材上での衝突時に跳 ね返されることによって、原料粉末よりかなり少なくなっ ている。しかし、対応する焼結体よりは相当程度硬く、こ れはバインダー相の硬度が高いことを示している。また、 $\mathrm{WC}$ 粒子径への依存性も焼結体に比べて非常に小さく、WC 径が細かくても必ずしも硬度が高い結果とはなっていな い。Fig.8は研磨した断面にビッカース圧子を押し込み、 発生したクラックの長さから破壊抵抗值を求めた結果であ る。組成にかかわらず $5 \mathrm{MPam}^{1 / 2}$ 以下の低い值しか得られ ておらず、試験後の亀裂経路を調べるとバインダー相中の Wリッチの部分が優先的に割れており、脆性な組織である ことが分かる。Fig.7と 8 のデー夕は、HVOF 溶射 WC-Co

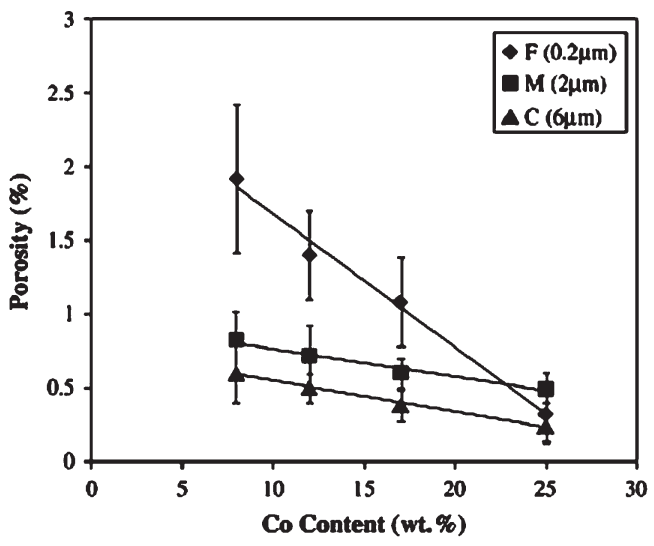

Fig.6 Porosity of HVOF WC-Co coatings as a function of Co content ${ }^{6}$.

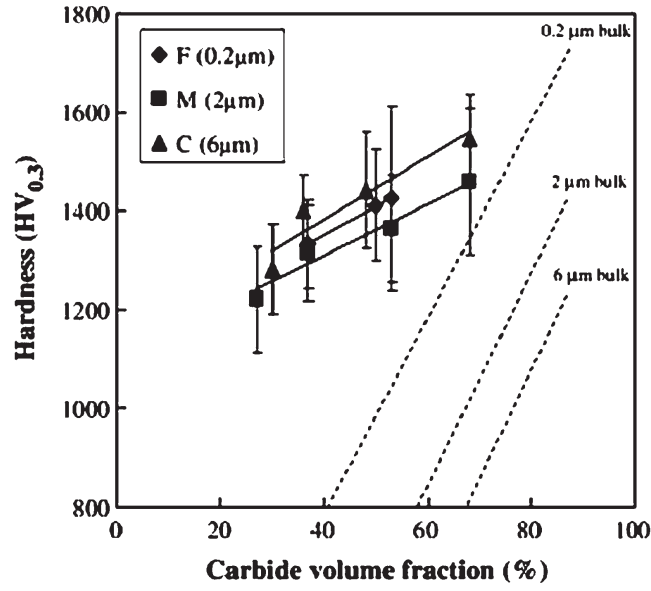

Fig.7 Hardness of of HVOF WC-Co coatings as a function of carbide volume fraction. The hardness of typical sintered WC-Co are also indicated by the dashed lines for comparison ${ }^{6}$.

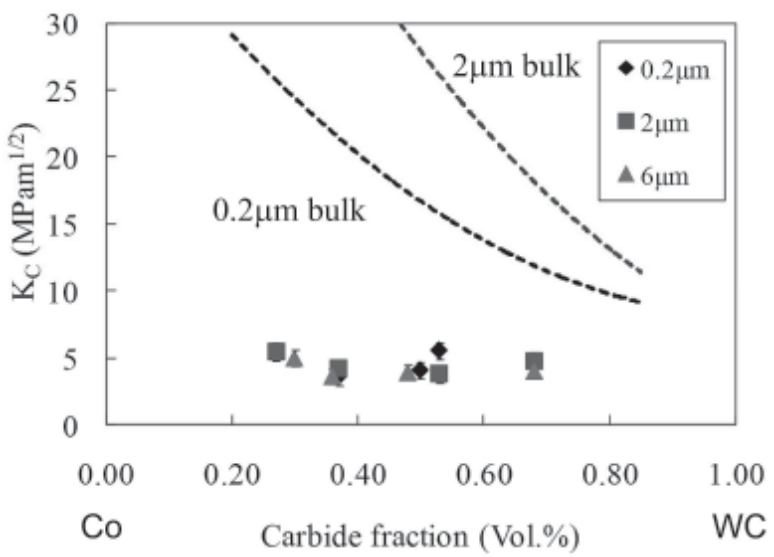

Fig.8 Fracture resistance HVOF WC-Co coatings as a function of carbide volume fraction evaluated from the lengths of the cracks induced by the Vicker's indentation on the cross sections. The values of typical sintered WC-Co are also indicated by the dashed curves for comparison. 


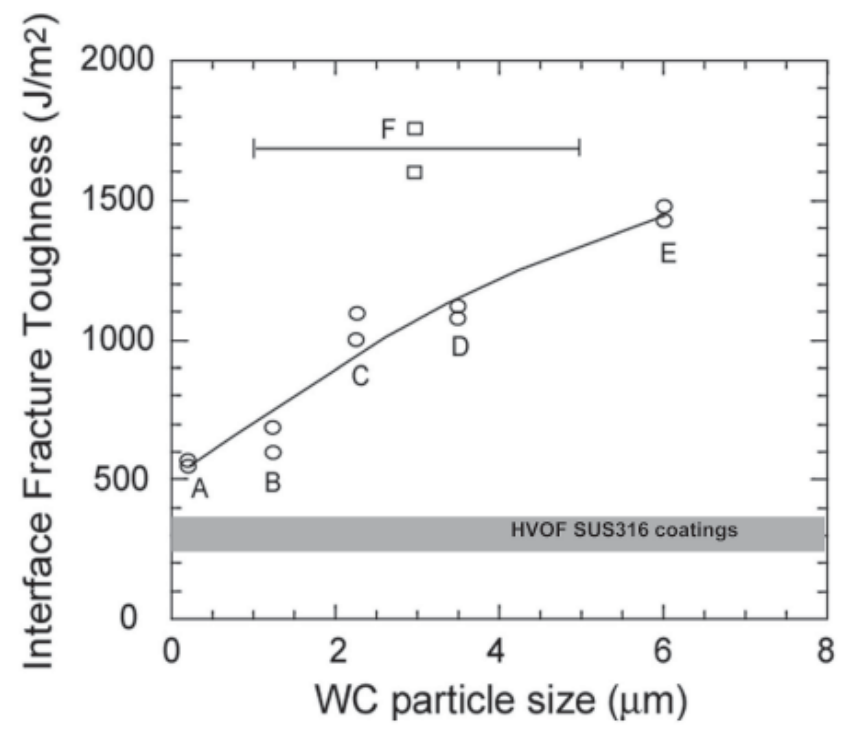

Fig.9 Interface facture toughness of HVOFWC-12 Co coatings with various WC particles sizes ass evaluated by the 4 point bending test with a pre-crack ${ }^{3)}$.

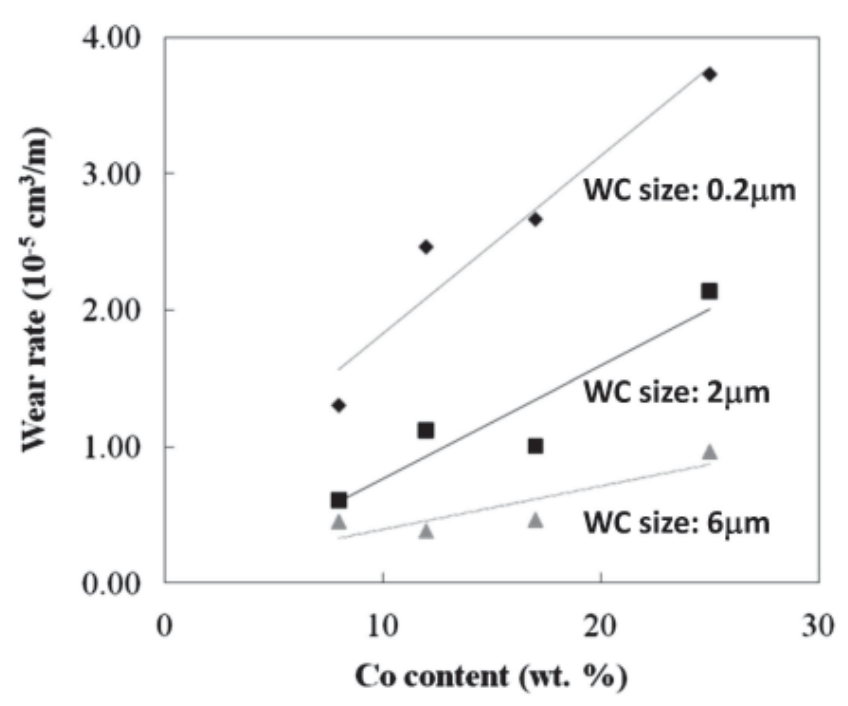

Fig.10 Abrasive wear resistance of various HVOF WC-Co coatings evaluated by the Suga abrasion tests.

皮膜の基本的な機械特性の特徵と焼結体との違いをよく表 わしている。

Fig.9 は渡邊による皮膜の密着性に関する結果である ${ }^{3)} 。$ 4 点曲げの試験片の引っ張り側に皮膜を形成し、皮膜中に 縦方向の予亀裂を導入後、曲げ試験を行い、亀裂が皮膜と 基材の界面を走って皮膜がはく離した時の荷重から皮膜と 基材の界面勒性值が計算された。同一メーカの粉末 (A-E) については、WC 粒子径が大きいほど界面勒性值は高くな り強い密着性があることが分かった。この傾向は、皮膜一
基材界面で WC 粒子が鋼基材へ食い达む効果によって定性 的に説明された。

Fig.10 はスガ摩耗試験の結果である。Co 量が多いほど、 また WC 粒子径が細かいほど摩耗量が多くなることが示さ れている。焼結体では、WC 微粒化による耐摩耗性の向上 が報告されており ${ }^{14)}$ ＨVOF 溶射では同様の効果が必ずし も得られないことを示している。

以上に述べた研究では、HVOF 溶射条件は一定であるの で、同一材料でもプロセス条件を変化させれば異なる結果 が得られる可能性があることは、注意が必要である。

\section{5. ウォームスプレー法}

近年、黒田、川喜多ら ${ }^{10,15)}$ は従来の HVOF 溶射法を改良 したウォームスプレーを開発し、これまで大気中では困難 であった純度の高いチタン皮膜の作成に成功した。Fig.1 (a), (b)にHVOF 溶射法とWS 法の原理図を示したが、WS 法で は、フレーム温度を $500 \sim 2000{ }^{\circ} \mathrm{C}$ の範囲内において制御 することによってスプレーされる粒子の温度を制御し、そ の融点以下で粒子を固相状態のままスプレーすることや、 酸化や溶解といった反応を抑制することが可能となってい る。前述したように従来の WC-Co 溶射皮膜の脆さの要因は、 極短時間とはいえ高温のフレームにさらされることによる 脱炭や反応相の生成といわれている。そのため、飛行粒子 の温度を WC と Co の共晶温度である $1310{ }^{\circ} \mathrm{C}$ 程度に下げる ことができれば、低勒性な $\eta$ 相の生成を抑えた皮膜を得る ことが期待できる。また、低温化により大気との反応に伴 う脱炭の抑制も期待できる。この場合、WC-Co 原粉末は固 相状態のまま基材へ衝突することになるため、従来の原粉 末を溶かして基材へ密着させるいわゆる”溶射”とは、根 本的に異なる密着プロセスを有している。このような背景 のもと、渡邊ら ${ }^{16)}$ および P. Chivavibul ら ${ }^{17,18)}$ は、WS 法を WC-Co 皮膜の成膜に適用し、その皮膜組織、力学特性につ いて詳細な研究を行った。

\subsection{WC-Co スプラット組織}

Fig.11に、HVOF 溶射およびWS 法それぞれにより得ら れた、単一粒子が基材へ衝突・密着した組織（以降、スプラッ トと呼ぶ)の比較写真を示す ${ }^{16)}$ 。それぞれ (a) HVOF 溶射、(b) WS (窒素量 : $500 \mathrm{~L} \cdot \mathrm{min}^{-1}$ )、(c) WS (窒素量 : $1500 \mathrm{~L} \cdot \mathrm{min}^{-1}$ ) に対応しており、上段がスプラット全体像、下段 (d) (e)が 中央部組織の高倍率像になっている。HVOF 溶射スプラッ トの溶融組織が、基材に衝突し飛散、凝固した典型的な組 織を示しているのに対して、WS のスプラットは紙面垂直 方向に扁平した楕円状にて基材にくいこんでおり、固相に 近い状態で衝突したことを示している。特に窒素量 1500 $\mathrm{L} \cdot \mathrm{min}^{-1}$ の場合、スプラット内の組織は角張った粗粒から なっており、粒子温度が低かったことを物語っている。一 方で、窒素量 $500 \mathrm{~L} \cdot \mathrm{min}^{-1}$ の場合、スプラット全体として 


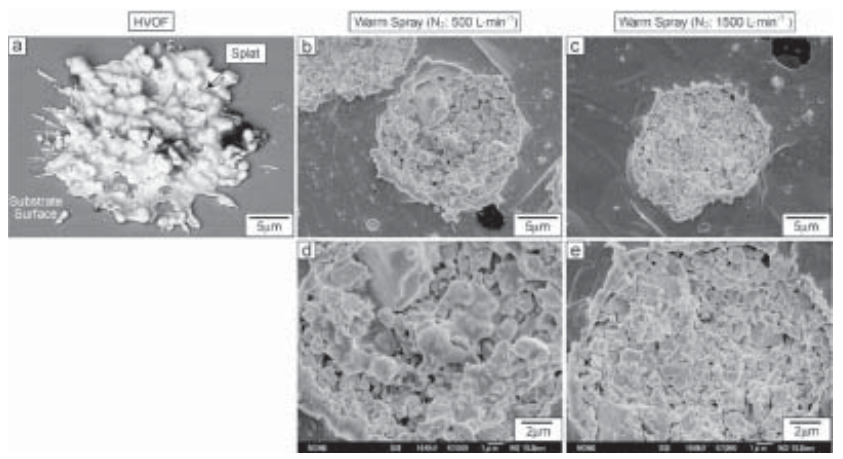

Fig.11 Splat microstructures deposited by (a)HVOF, (b)(d)Warm Spray with nitrogen flow rate of 500L $\mathrm{min}^{-1}$, and (c)(e) Warm Spray with nitrogen $1500 \mathrm{~L} \cdot \mathrm{min}^{-1}$. (d)and(e) are higher magnification images of (b) and (c) respectively.

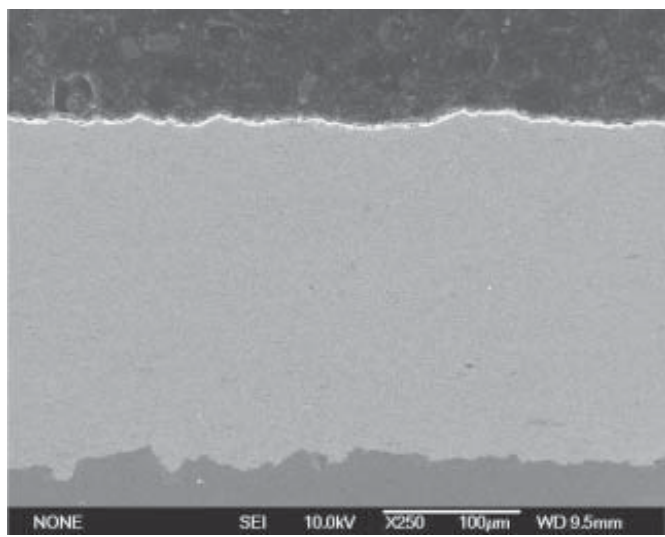

Fig.12 Cross sectional image of a coating deposited by Warm Spray deposition.

は固相に近かったと考えられるが、細部を見るとWC の周 りに固溶体の形成もしくは液相が覆っていたことが認めら れ、窒素量の違いにより飛行粒子の温度が大きく变化して いることを裏付けている。WSに扔いて窒素量がゼロの状 態は、HVOF 溶射にほかならない。したがって、Fig.11は WS により WC-Co 粒子の状態を溶融状態から固相状態まで シームレスに制御できることを意味しており、本プロセス の特長を明確に示している。また、窒素量 $1500 \mathrm{~L} \cdot \mathrm{min}^{-1}$ の 場合、多数の空隙がスプラット内に存在している。皮膜は スプラットの連続堆積により形成されるため、ほぼ完全な 固相状態にて衝突しているこの条件では、これら微細な空 隙を以降の粒子の衝突により接合していくことは困難と推 測され、緻密な皮膜を得ることは難しいと予想される。

\subsection{WC-Co コーティング組織}

Fig.12にWS にて作成した皮膜（窒素流量： $500 \mathrm{~L} \cdot \mathrm{min}^{-1}$ ) の断面 SEM 像を一例として示す ${ }^{16}$ 。写真から明らかなよ うに、厚さ $300 \mu \mathrm{m}$ 以上の緻密な皮膜を得ることができる。
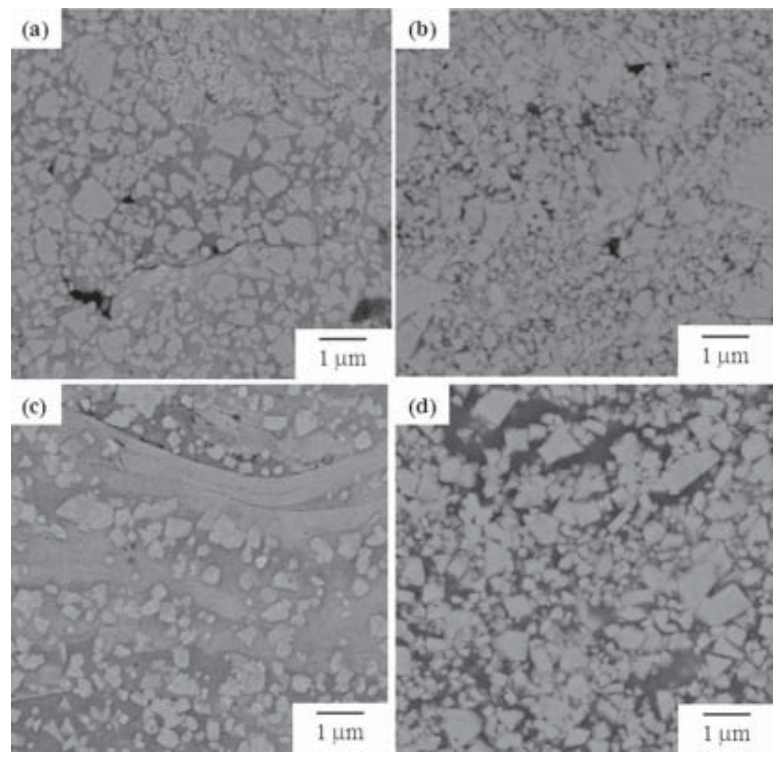

Fig.13 SEM observations of (a) HVOF WC-12 Co, (b) WS WC-12 Co, (c) HVOF WC-25 Co, and (d) WS WC-25 Co coatings ${ }^{17}$.

さらにFig.13には、12 wt \% 抒よび $25 \mathrm{wt} \%$ の異なるCo 量を含む原粉末（WC 粒径 $0.2 \mu \mathrm{m}$ 、二次粒子径：15 45 $\mu \mathrm{m})$ を、HVOF 法掞よびWS 法により成膜し、得られた 皮膜の組織を示す ${ }^{17}$ 。そそれぞれ、(a) HVOF WC-12 Co、(b) WS WC-12 Co、(c) HVOF WC-25 Co、(d) WS WC-25 Co の 組織写真である。適用した成膜条件を Table 1 に示す。白 い粒子が WCであり、粒子間の灰色であらわされる領域が Co バインダー相である。 HVOF 溶射皮膜（Fig.13 (a) (c)） では、WC 粒子の角が取れ丸まっている。これはプロセス 時の高温にさらされることにより、Co バインダー相内へと 溶解した結果である。また、バインダー相は濃い灰色の領 域もあれば薄い灰色の部分もあり、まだらな色合いの積層 となっている。各粒子の温度履歴の差に依存して溶解の程 度が異なり、不均一な組織となっていることが理解できる。 EDSによる分析の結果、白いバインダー相はタングステン が豊富に溶け込んだ領域であり、濃い灰色の部分は相対的 にタングステン量が少ないコバルトを主とした組織であっ た。これに対してWSにより作成された皮膜 (Fig.13 (b) (d)) は、HVOF 皮膜と比較すると WCがより角張っており、ま た白い WC の領域と濃い灰色のバインダー相の二色のみで 構成されている。焼結バルク体に極めて類似した組織であ る。さらに、それぞれの Co 量で得られた組織を HVOF お よびWSで比較した場合、明らかにWS 皮膜中の炭化物の 体積率が、HVOF 中のそれよりも多いことが理解される。 特にこの傾向は、Co 量の多い $25 \% \mathrm{Co}$ 原粉末を利用した場 合に顕著である。したがって、同じ原粉末を利用しても、 HVOF では溶解や脱炭反応により、炭化物体積率が減少す るのに対し、WSではより多くの炭化物粒子を皮膜中に残 


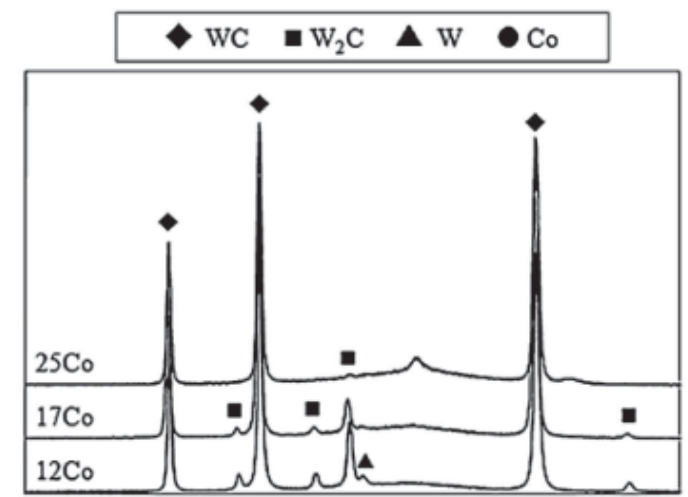

(a)

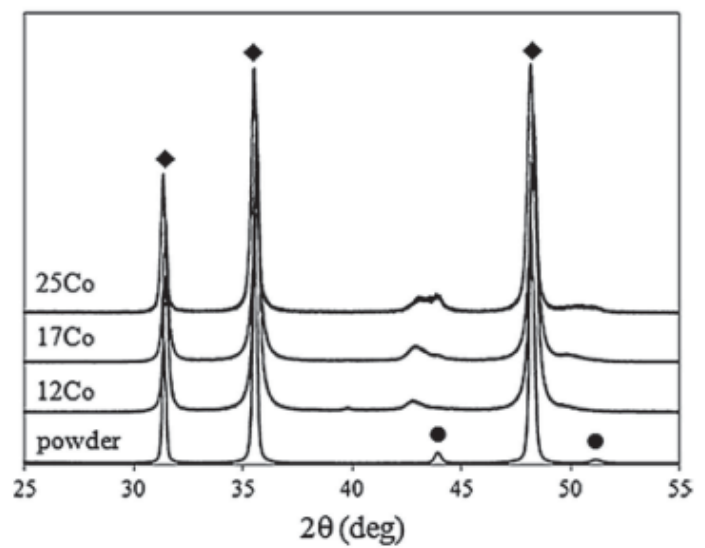

(b)

Fig.14 XRD spectra of (a) HVOF and (b) WS coatings. The result of WC-12 Co powder is given for a comparison ${ }^{177}$.

存させることが可能である。

Fig.14には、Co 量 12, 17, $25 \mathrm{wt} \%$ の原粉末（WC 粒径： $0.2 \mu \mathrm{m})$ より作製した皮膜のXRD 分析結果を、(a) HVOF および (b) WS の両ケースについて示している ${ }^{17)}$ 。成膜条件 はTable 1 と同じである。Fig.14 (b) には原粉末の測定結果 も伴わせて示している。HVOF 溶射皮膜の場合、40 近辺 に明瞭なピークがある。また 30 50 全域に渡ってハロー パターンを示しており、皮膜内に $\mathrm{W}_{2} \mathrm{C}$ やアモルファス相が 形成していることが分かる。一方、原粉末、そしてWS 皮 膜では $\mathrm{W}_{2} \mathrm{C}$ 相やアモルファス相に対応するようなパターン は認められない。したがって、少なくとも X 線回折により 捕捉できるレベルでは、WS 皮膜は、WC および Co 相から 構成されているといえる。ただし、Coのピーク位置に注目 すると、12 Co、 17 Co では低角度側へ移動するとともに半 值幅も大きくなり、25 Co の場合では、二つのピークとなっ ていることが認められる。このピークシフトの要因につい ては、まだ十分に解明されていないが、ローカルな領域で の Co 層への W、C 元素の固溶、もしくは高速衝突に伴う Co 層内への大きな残留ひずみの導入および結晶粒の微細化 によるものではないかと考えられる。

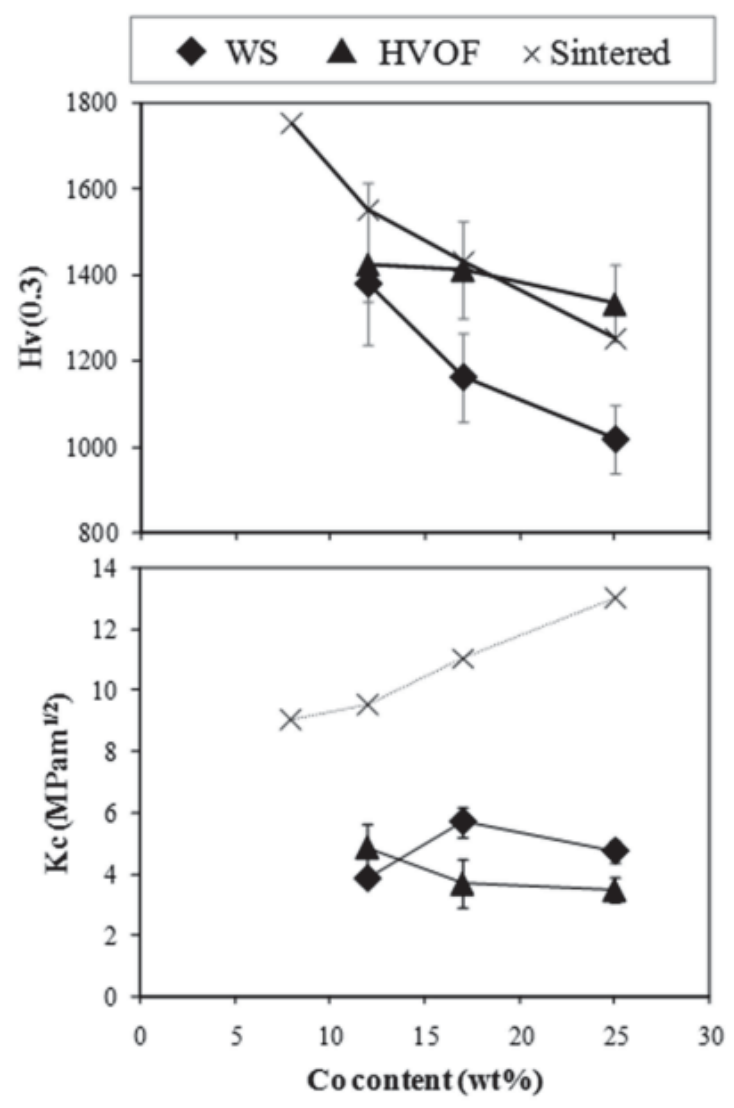

Fig.15 (a) Hardness and (b) fracture resistance as a function of cobalt content. Values of the sintered materials were given for a comparison ${ }^{17)}$.

5.3 WC-Co コーティング組織

前節で示した試料のビッカース硬さと原粉末中の炭化物 体積率の関係を Fig.15（a）に示す ${ }^{17)}$ 。ビッカース硬さは 荷重 $300 \mathrm{~g}$ 重、保持時間 15 秒にて測定された。HVOF 皮膜 の場合、原粉末中の Co 量と硬さの間にあまり相関が認め られない。これは、溶射時に Co バインダー中へ W、 C 元 素が溶融し、バインダー自体の硬度が増加しているためと 考えられる。一方で、WS 皮膜では、Co 量の増加に伴い、 硬さが減少していく傾向を示し、×印で示される焼結バル ク体と同様な傾向となっている。このことは、WS 皮膜が 焼結バルク体と同様の組成からなることを毫付けている。 ただし、この試験片の場合、両者の間には $200 \mathrm{Hv}$ 程度の差 があり、WS 皮膜の方が焼結体よりも柔らかい。また、焼 結体の傾向から、WSにおいて、よりCo 量の少ない皮膜 を成膜できれば、さらに硬度の高い皮膜が得られるものと 推定される。Fig.15 (b)には、IF 法により測定した破壊抵 抗 $K_{c}$ の評価結果を示している ${ }^{17)}$ 。破壊抵抗の評価はビッ カース硬さ試験機において、荷重 $10 \mathrm{~kg}$ 重を負荷し、生じ るき裂長さから評価している。HVOF の場合、 12 Co が約 5 $\mathrm{MPa} \cdot \mathrm{m}^{1 / 2}$ もっとも破壊抵抗が高く、Co 量が $17,25 \mathrm{wt} \%$ と 
減少するにつれ、3 4 MPa $\cdot \mathrm{m}^{1 / 2}$ と破壊抵抗は低下していく。 WS 皮膜の場合は傾向が異なり、12 Co 皮膜が最も脆く約 4 $\mathrm{MPa} \cdot \mathrm{m}^{1 / 2} 、 17 \mathrm{Co}$ 皮膜が最も破壊抵抗が高く約 $6 \mathrm{MPa} \cdot \mathrm{m}^{1 / 2}$ 、 $25 \mathrm{Co}$ 皮膜では再び減少し、約 $5 \mathrm{MPa} \cdot \mathrm{m}^{1 / 2}$ 程度となってい る。図中に示されているように、焼結バルク体では、柔ら かい Co バインダー相の増加に伴い単調に増加することか ら、WS 皮膜の傾向はバルク焼結体と異なっていることが 理解できる。WS に扔ける固相粒子の密着が、主にCo バイ ンダー相を介してなされているためと考えられ、Co 量が少 ない場合、気孔やき裂などの未接合部が生じ、破壊抵抗值 が低くなっているものと考えられる。一方、WSにより作 製された 17 Co では HVOF に比べ大きな破壊抵抗の上昇が 認められるが、25 Co では 17 Co よりも低い值となっている。 この原因については、現在のところ不明である。いずれに しろ、バルク焼結体の值と比較すると、その差は未だ大き く今後の研究の進展が待たれる。

Fig.16には同条件で作製した試料についてスガ摩耗試 験を行った結果について示す ${ }^{177}$ 。荷重 $3 \mathrm{~kg}$ 重、研磨紙 $\mathrm{SiC}$ \#180、摩耗距離 $25.6 \mathrm{~m}$ にて試験を行った。また、表面性 状の影響を除去するために、試料表面を研磨後、試験を開 始した。縦軸の体積摩耗量とは、基材である炭素鋼（JIS SS400）を同条件で摩耗試験に供し、その際の重量減少值 により、各試験で得られた重量減少值を規格化した值であ る。したがって、1であれば、基材と同じ耐摩耗性という ことになり、值が小さいほど優れた耐摩耗性を持つといえ る。HVOF、WS 皮膜とも、Co 量が少ない皮膜程、優れた 耐摩耗性を示した。特に 12 Co の場合、WS 皮膜は HVOF 皮膜よりも約 $30 \%$ 程度、高い耐摩耗性を示した。一方で $25 \mathrm{Co}$ の場合、WS 皮膜は HVOF よりも若干低い值となった。 Fig.15では、HVOF と WSにより作製された 12 Co 皮膜の 硬さはほほ同程度であったが、Fig.14の XRD 結果で示し たように、HVOF 皮膜では、もろい $\mathrm{W}_{2} \mathrm{C}$ 相など劣化相の生 成が生じている。このため、硬さは同程度であっても、そ の耐摩耗性という点では大きく差が出たものと思われる。 Co 量が多い原粉末の場合、HVOF と比べWS 皮膜は柔らか く、耐摩耗性が低いと考えられるが、バインダー相の脆化 したHVOF と比べ、WS では Co バインダー相が延性を維 持して㧍り、明暸な差が認められなかったものと考えられ る。

\section{4 微粉末の適用}

前節までの結果は二次粒子径 $15 \sim 45 \mu \mathrm{m}$ の原粉末を使っ たものであった。これに対し、当グループでは二次粒径 5 〜 $20 \mu \mathrm{m}$ の原粉末を用いることにより、皮膜の硬さとスプ レーしたままでの表面平滑性の改善に成功している。

Fig.17 に WC-12 Co 皮膜の表面平滑性とビッカース硬さ の分布を示す。 $D_{p}$ は原料粉末の粒径を意味する。図中、白 抜きのシンボルが一般的な粉末を用いた HVOF のもの、黒

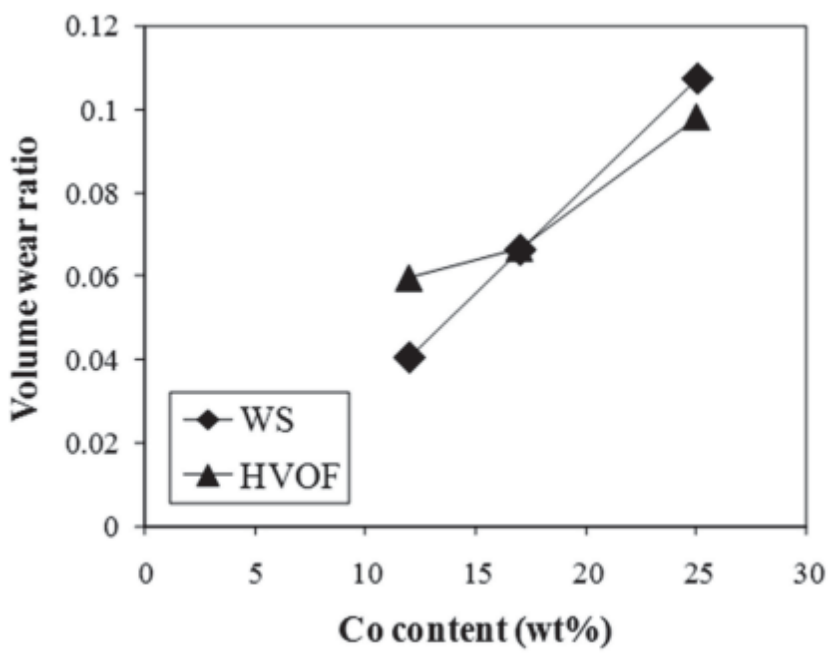

Fig.16 Suga wear ratio as a function of Co content ${ }^{17)}$.

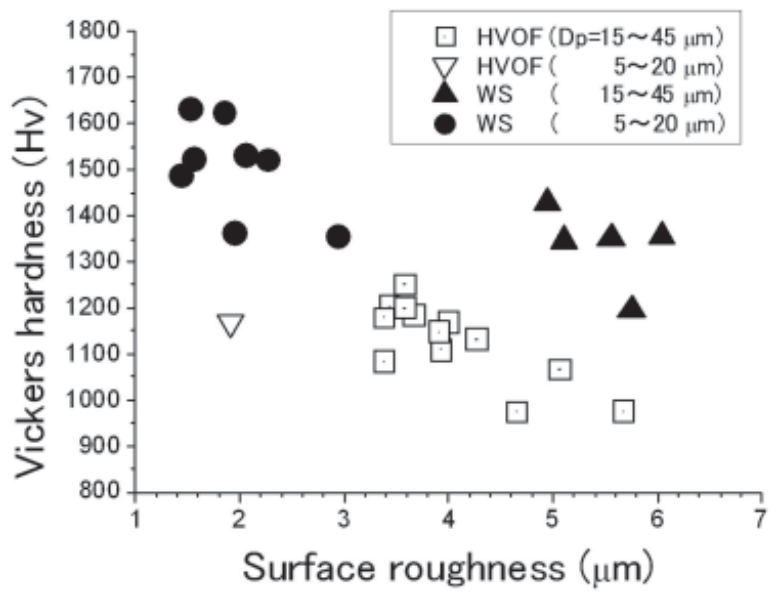

Fig.17 Map of surface roughness and Vickers hardness HVOF and WS coatings for different particle size.

のシンボルがWS の結果を示している。図から明らかなよ うに、二次粒径 5 20 $\mu \mathrm{m}$ の粉末を利用することにより、ビッ カース硬さ約 $1600 \mathrm{Hv}$ 、表面平滑性約 $1.6 \mu \mathrm{m}$ をWS 皮膜で は達成して扔り、一般的な HVOF 皮膜の結果と比べ、大幅 な改善を達成している。また、HVOFに扔いても、5〜20 $\mu \mathrm{m}$ の粉末を用いると表面平滑性の改善が認められる。し かし、このような微粉末は、溶融しやすく、ノズル内壁に 付着し閉塞させるいわゆるスピッティングという現象を生 じさせやすい。このため、実際の製品に使用することは困 難である。一方で、WS の場合、固相粒子のまま成膜させ るため、上記のようなノズル閉塞の問題は、WC-Co では生 じない。このため、より細かい粉末の利用などにより、さ らに硬さと平滑性が改善されることも期待できる。 


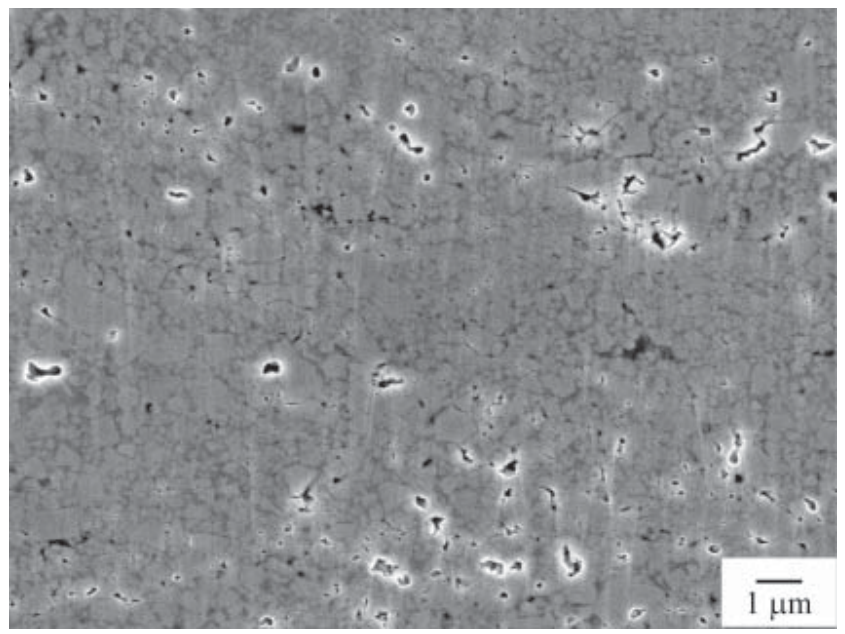

Fig.18 Cross sectional image of WC-12 Co coating (WC size: $0.2 \mu \mathrm{m}$ ) prepared by cross section polisher ${ }^{18)}$.

\subsection{WS WC-Co の課題}

これまで見てきたように、WS 法により得られる WC-Co 皮膜は、焼結バルク体と同傾向の特性を有しており、今後 の開発により、極めて優れたコーティングとなり得る。本 節ではそのために解決されるべき課題について述べる。一 つ目は、未接合部の問題である。Fig.18に、Arイオンビー ムにより研磨した WS 皮膜 (WC-12 Co, 二次粒径 5〜20 $\mu \mathrm{m} ）$ の断面写真を示す ${ }^{18)}$ 。写真から明らかなように大き さ $1 \mu \mathrm{m}$ 以下の微小な欠陥が多数存在することが認められ る。Fig.13ではこのような欠陥が認められないが、これは 機械研磨のために、柔らかいCoバインダー相が塑性変形 し、欠陥を埋めてしまっているためと考えられる。このよ うな微小欠陥は、荷重負荷時に応力集中源となり、破壊が 生じる要因となる。Fig.15で見られるバルク焼結体との破 壊抵抗值の差は、これら微小欠陥の存在によるものと考え られる。これらの欠陥をいかに減らすことができるかは、 WC-Coのみに限らず、固相粒子の衝突現象を利用したコー ティング技術、共通の課題といえる。二つ目に、付着効率 の問題である。現在のところ、WSによるWC-Co の付着効 率はおよそ 20 〜 $25 \%$ である。 HVOF では 40〜 $50 \%$ 弱で あるため、HVOF と比較した場合、約半分程度となる。付 着効率の低下は、作業時間や納期、ガスや消耗品の使用料 に直結し、コストを大きく増加させることになる。このた め、付着効率をいかに改善できるかも、今後の大きな課題 である。

\section{6. 結 言}

WC-Co を HVOF 溶射した皮膜は産業界で広く用いられ ているが、その組織や特性は焼結体とはかなり異なり、ま た成膜条件によっても変化する。その主原因は、バインダー
相の融点以上の温度への加熱と基材上での急冷である。 従来の WC-Co 皮膜の性能を改善し、スプレーコーティ ング技術によるWC-Co の応用範囲を広げていく上で、 ウォームスプレー法は非常に有望な技術である。この技術 により、従来の高速フレーム溶射法では実現することので きない脆性な脱炭相やアモルファス相の検出されない焼結 バルク体に近い組成と組織を有する厚膜の作成が可能であ る。さらに、二次粒径 5 $20 \mu \mathrm{m}$ の微粉末と組み合わせる ことにより、ビッカース硬さ $1600 \mathrm{Hv}$ 、表面粗さ $1.6 \mu \mathrm{m}$ を スプレーしたままの状態で実現している。一方で、破壊抵 抗值や耐摩耗性をバルク焼結体と比較すると未だ開きがあ る。この要因として、皮膜内の微視欠陷の存在が考えられ、 今後、プロセスパラメータおよび原粉末組織と、皮膜組織 や特性の相関について明らかにし、最適化を図っていくこ とが必要である。

WC-Co 以外の材料系についても、今後、検討が必要であ る。また、コールドスプレーによるサーメット皮膜の研究 も進められており ${ }^{19,20)}$ 、WC-Co よりも容易に成膜できる粉 末材料なども発表されている。

\section{謝 辞}

本稿は多数の共同研究者との共同研究の成果を多く含ん でいる。NIMSの川喜多仁主幹研究員、小松誠幸主任エン ジニア、P. Chivavibul 博士、石川康成博士、G.S. Raman 教授、 フジミインコーポレーテッドの北村順也博士、佐藤和人氏 に心より謝意を表する

\section{引用文献}

1) G. S. Upadhyaya, Cemented Tungsten Carbides. Production, Properties, and Testing. (Noyes, New Jersey, 1998).

2) Y. Baba, Mineral Resources Report 35 (2005) 69-78.

3) M. Watanabe, A. Owada, S. Kuroda and Y. Gotoh, Surf. Coat. Technol. 201 (2006) 619-627.

4) Y. Ishikawa, S. Kuroda, J. Kawakita, Y. Sakamoto and M. Takaya, Surf. Coat. Technol. 201 (2007) 4718-4727.

5) J. M. Guilemany, S. Dosta and J. R. Miguel, Surf. Coat. Technol. 201 (2006) 1180-1190.

6) P. Chivavibul, M. Watanabe, S. Kuroda and K. Shinoda, Surf. Coat. Technol. 202 (2007) 509-521.

7) M. M. Lima, C. Godoy, J. C. Avelar-Batista and P. J. Modenesi, Mater. Sci. Eng. A-Struct. Mater. Prop. Microstruct. Process. 357 (2003) 337-345.

8) C. Verdon, A. Karimi and J. L. Martin, Mater. Sci. Eng. A-Struct. Mater. Prop. Microstruct. Process. 246 (1998) 11-24.

9) J. M. Guilemany, J. M. de Paco, J. Nutting and J. R. Miguel, Metall. Mater. Trans. A-Phys. Metall. Mater. Sci. 30 (1999) 1913-1921.

10) S. Kuroda, J. Kawakita, M. Watanabe and H. Katanoda, Science and Technology of Advanced Materials 9 (2008) 033002.

11）北村順也、サーメット材料、「溶射工学便覧」、沖幸男、上野 
和夫編 (日本溶射協会、東大阪、2009) p. 160-185.

12) J. M. Guilemany, J. M. d. Paco, J. Nutting and J. R. Miguel, Metal. Mater. Trans. A 30 (1999) 1913-1921.

13) A. K. a. J. L. M. C. Verdon, Mater. Sci. Eng. A 246 (1998) 11-24.

14）鈴木壽、林浩宏爾、超硬合金の機械的性質、”超硬合金と焼結 硬質材料 基礎と応用”、鈴木壽編 (丸善、東京、1986) p. 122.

15) J. Kawakita, S. Kuroda, T. Fukushima, H. Katanoda, K. Matsuo and H. Fukanuma, Surf. Coat. Technol. 201 (2006) 1250-1255.

16）渡邊誠、ポーンテープ・チバヴィブル、黒田聖治、川喜多仁、 小松誠幸、北村順也、佐藤和人 日本金属学会誌 71 (2007)
853-859.

17) P. Chivavibul, M. Watanabe, S. Kuroda, J. Kawakita, M. Komatsu, K. Sato and J. Kitamura, J. Therm. Spray Technol. 17 (2008) 750-756.

18) P. Chivavibul, M. Watanabe, S. Kuroda, J. Kawakita, M. Komatsu, K. Sato and J. Kitamura, J. Therm. Spray Technol. 19 (2010) 81-88.

19) R. S. Lima, J. Karthikeyan, C. M. Kay, J. Lindemann, and C. C. Berndt, Thin Solid Films 416 (2002) 129-135.

20) H. J. Kim, C. H. Lee and S. Y. Hwang, Mater. Sci. Eng. A 391 (2005) 243-248. 